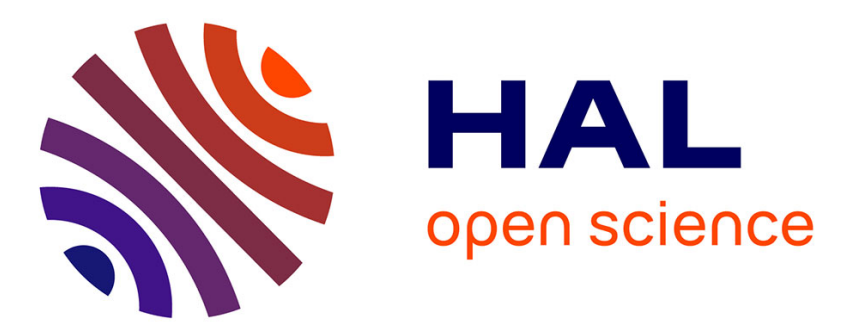

\title{
Bioaccumulation of PCBs in the cuttlefish Sepia officinalis from seawater, sediment and food pathways
}

Bruno Danis, Paco Bustamante, Olivier Cotret, Jean-Louis Teyssié, Scott W. Fowler, Michel Warnau

\section{- To cite this version:}

Bruno Danis, Paco Bustamante, Olivier Cotret, Jean-Louis Teyssié, Scott W. Fowler, et al.. Bioaccumulation of PCBs in the cuttlefish Sepia officinalis from seawater, sediment and food pathways. Environmental Pollution, 2005, 134 (1), pp.113-122. 10.1016/j.envpol.2004.07.010 . hal-00225647

\section{HAL Id: hal-00225647 \\ https://hal.science/hal-00225647}

Submitted on 30 Jan 2008

HAL is a multi-disciplinary open access archive for the deposit and dissemination of scientific research documents, whether they are published or not. The documents may come from teaching and research institutions in France or abroad, or from public or private research centers.
L'archive ouverte pluridisciplinaire HAL, est destinée au dépôt et à la diffusion de documents scientifiques de niveau recherche, publiés ou non, émanant des établissements d'enseignement et de recherche français ou étrangers, des laboratoires publics ou privés. 


\section{Bioaccumulation of PCBs in the cuttlefish Sepia officinalis from seawater, sediment and food pathways}

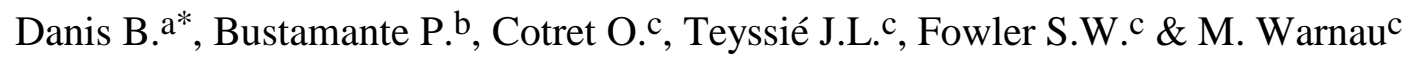

a. Laboratoire de Biologie Marine (CP 160-15), Université Libre de Bruxelles, 50 Av. F.D. Roosevelt, B-1050 Brussels, Belgium

b. Laboratoire de Biologie et Environnement Marins, UPRES-EA 3168, Université de La Rochelle, 22 Av. Michel Crépeau, F-17042 La Rochelle Cedex, France

c. Marine Environment Laboratory - International Atomic Energy Agency, 4 Quai Antoine $\mathrm{I}^{\mathrm{er}}$, MC-98000 Monaco

Correspondance: Bruno DANIS

Laboratoire de Biologie marine (CP 160/15)

Université Libre de Bruxelles

Av. F.D. Roosevelt 50

B-1050 Brussels, Belgium

Phone: (+32) 26502970

Fax: (+32) 26502796

E-mail: bdanis@ulb.ac.be 


\section{ABSTRACT}

The cuttlefish Sepia officinalis was selected as a model cephalopod to study PCB bioaccumulation via seawater, sediments and food. Newly hatched, juvenile cuttlefish were exposed for 17 days to environmentally realistic concentrations of ${ }^{14} \mathrm{C}$-labeled $2,2^{\prime}, 4,4^{\prime}, 5,5^{\prime}-$ hexachlorobiphenyl (PCB\#153) (18 ng PCB ${ }^{-1}$ seawater; 30 ng PCB g g $^{-1}$ dry wt sediments ; Artemia salina exposed to $18 \mathrm{ng}$ PCB $1^{-1}$ seawater). Accumulation of PCB\#153 was followed in three body compartments : digestive gland, cuttlebone and the combined remaining tissues. Results showed that (1) uptake kinetics were source- and body compartment-dependent, (2) for each body compartment, the accumulation was far greater when S. officinalis was exposed via seawater, (3) the cuttlebone accumulated little of the contaminant regardless of the source, and (4) the PCB congener showed a similar distribution pattern among the different body compartments following exposure to contaminated seawater, sediment or food with the lowest concentrations in the cuttlebone and the highest in the remaining tissues. The use of radiotracer techniques allowed delineating PCB kinetics in small whole organisms as well as in their separate tissues. The results underscore the enhanced ability of cephalopods to concentrate organic pollutants such as PCBs, and raise the question of potential risk to their predators in contaminated areas.

Keywords: Cephalopods ; Persistent Organic Pollutants ; Kinetics ; Transfer ; Distribution 


\section{INTRODUCTION}

Among persistent organic pollutants (POPs), polychlorobiphenyls (PCBs) are a class of anthropogenic contaminants of long-standing environmental concern (Livingstone et al 2000). Represented by 209 congeners, PCBs are widespread, highly conservative and are readily accumulated in living organisms. PCBs entering marine waters become available for marine organisms whose biology can be affected at various organizational levels (Metcalfe 1994). Moreover, these contaminants may also be biomagnified in food webs raising a potential risk for high trophic level predators. Marine invertebrates take up these contaminants via three main routes: ambient seawater (through gills and body surfaces), direct contact with sediments, and ingestion of food. Previous studies using sea stars and sea urchins (Danis et al. 2003a,b) have shown that the efficiency of PCBs bioaccumulation depends on the source of contamination (viz. seawater is probably the main contamination source) and on the considered congener (Danis \& Warnau, in prep.).

Cephalopods, including benthic (octopus), nectobenthic (cuttlefish), neritic and oceanic (squids) species, are widely distributed in the world oceans. They generally display short life span and high growth rates. Owing to the economic value of many cephalopod species, they are of high commercial interest for fisheries (Forsythe \& Heukelem 1987, Navarro \& Villanueva 2000). Moreover, cephalopods play key roles in marine ecosystems, being both active predators of fish and crustaceans (Castro \& Guerra 1990, Rodhouse \& Nigmatullin 1996) and important prey items for marine mammals, seabirds and fish (Clarke 1996, Croxall \& Prince 1996, Klages 1996, Smale 1996). Therefore, cephalopods can be considered as an important vector for transferring potentially hazardous contaminants to top marine predators (Bustamante et al. 1998, Weisbrod et al. 2000, 2001).

Cephalopods are known to accumulate numerous contaminants among which are POPs such as organochlorine pesticides or PCBs (Tanabe et al. 1984, Kawano et al. 1986, Yamada et al. 1997, Weisbrod et al. 2000, 2001, Ueno et al. 2003). However, very little is known about 
bioaccumulation capacity depending upon the routes of exposure to these contaminants; such data are needed to further assess the potential impact of organic pollutants on cephalopod populations. For these reasons, experiments were designed to study the bioaccumulation of PCBs by the common cuttlefish Sepia officinalis following exposure via seawater, sediments and food.

PCB biokinetics were determined using radiotracer techniques in order to measure fluxes at environmentally realistic concentrations (Danis et al. 2003a,b). These techniques have already proven useful when examining kinetic behaviour in organs that are too small for employing classical PCB analytical measurements have to be considered. The PCB congener \#153 $\left(2,2^{\prime}, 4,4^{\prime}, 5,5^{\prime}\right.$ hexachlorobiphenyl) was selected as a model PCB, since it is the most abundant in marine biota and has been recognized as an indicator of total PCB contamination (see e.g., Stebbing et al. 1992, Atuma et al. 1996).

\section{MATERIALS AND METHODS}

Organisms. Seven- to nine-day old newly hatched cuttlefish (hereafter called juveniles) were used in the experiments. Cuttlefish eggs were spawned in the laboratory by adults collected by net fishing off Monaco and were maintained in aquaria until hatching. Young cuttlefish were kept in a separate aquarium (open circuit, $201 \mathrm{~h}^{-1}$ flow rate, constant aeration, 36 p.s.u., $16.5 \pm$ $0.5{ }^{\circ} \mathrm{C}, 12 \mathrm{~h} / 12 \mathrm{~h}$ light/dark cycle) and fed brine shrimp (Artemia salina) until used in the experiments.

Radiotracer. The PCB radiotracer $\left({ }^{14} \mathrm{C}\right.$-labelled 2,2',4,4',5,5'-hexachlorobiphenyl; purity $\geq$ 95\%) was purchased from Sigma Chemicals, USA. Specific activity was $925 \mathrm{MBq} \mathrm{mmol}^{-1}$ and stock solutions were prepared in acetone at a concentration of $1 \mu \mathrm{g} \mathrm{ml}^{-1}$ and stored at $-20^{\circ} \mathrm{C}$ until used.

Liquid scintillation counting. Water samples $(2 \mathrm{ml})$ containg the radiotracer were directly transferred to $20 \mathrm{ml}$ glass scintillation vials (Packard, USA) and mixed with $10 \mathrm{ml}$ of 
scintillation liquid (Ultima Gold XR ${ }^{\circledR}$, Packard, USA). Sediment and biota samples (cuttlefish tissues and brine shrimp) were ultrasonified twice for $10 \mathrm{~min}$, each time with $2 \mathrm{ml}$ of Acetonitrile $^{\circledR}$ (Packard, USA). This treatment produced a liquid phase $(4 \mathrm{ml})$ containing the extracted ${ }^{14} \mathrm{C}$-PCB and a residue. The residue was digested overnight at $70^{\circ} \mathrm{C}$ with $2 \mathrm{ml}$ of Soluene $^{\circledR}$ (Packard, USA) and mixed with $10 \mathrm{ml}$ of scintillation liquid (Hionic Fluor ${ }^{\circledR}$, Packard, USA). The liquid phase was added to $16 \mathrm{ml}$ of filtered seawater and extracted twice using $2 \mathrm{ml}$ of $\mathrm{n}$-Hexane (Sigma, USA) under agitation. The organic phase $(4 \mathrm{ml})$ and the aqueous phase $(20 \mathrm{ml})$ were treated separately. The whole organic phase, and $2 \mathrm{ml}$ of the aqueous phase were mixed separately with $10 \mathrm{ml}$ of Ultima Gold $\mathrm{XR}^{\circledR}$ scintillation liquid. The treatment is summarised in Figure 1.

B-emission of the tracer was measured in the samples using a 1600 TR Liquid Scintillation Analyzer (Packard). The counting time was selected to obtain counting rates with relative propagated errors less than 5\% (maximum counting duration: $2 \mathrm{~h}$ ). Radioactivity measured in the samples was compared to standards and corrected for quenching, background and physical decay of the tracer. PCB concentrations were expressed on a total lipid content basis where lipids were determined according to the method of Barnes \& Blackstock (1973).

\section{Experimental procedures.}

\section{Uptake from seawater.}

Juvenile cuttlefish (mean wet wt $\pm \mathrm{SD}=0.141 \pm 0.039 \mathrm{~g} ; \mathrm{n}=25$ ) were placed for $20 \mathrm{~d}$ in a 70 1 glass aquarium containing natural seawater spiked with $18 \mathrm{ng}{ }^{14} \mathrm{C}-\mathrm{PCB} \# 153 \mathrm{I}^{-1}$. This concentration corresponds to a moderate level of contamination in the North Sea (Stebbing et al. 1992). One day before starting the experiment, four 51 glass beakers were filled with filtered seawater (36 p.s.u., $16.5 \pm 0.5^{\circ} \mathrm{C}$ ), spiked with the PCB stock solution, and constantly stirred using an orbital agitation plate. Contaminated seawater was poured into the glass aquarium which was subsequently filled to a final volume of 701 with uncontaminated 
seawater. This operation (spiked seawater preparation) was performed daily throughout the duration of the experiment and radiolabeled seawater was renewed daily in the aquarium. Radioactivity was checked before and after each seawater renewal to assess the stability of the labeled PCB concentration. All cuttlefish were fed twice a day with Artemia salina and were periodically sampled. After $1 \mathrm{~h}$, uningested brine shrimp were removed to limit as much as possible incorporation of PCB through the food. At each sampling time, 3 individuals were dissected to determine the distribution of the radiotracer among digestive gland, cuttlebone and the remaining tissues.

\section{Uptake from sediments.}

Sediments (2.5 kg dry wt) from the North Sea (Audresselles, Pas-de-Calais, France) were contaminated for $4 \mathrm{~d}$ with the ${ }^{14} \mathrm{C}$-labeled PCB using the rolling jar method (Murdoch et al. 1997). Sediments were then placed in a 701 glass aquarium and maintained overnight under flowing seawater (open circuit, $201 \mathrm{~h}^{-1}$ flow rate, 36 p.s.u., $16.5 \pm 0.5{ }^{\circ} \mathrm{C}$ ) to allow any loosely bound contaminant to leach. The seawater level in the aquarium was then reduced so that a 2 $\mathrm{cm}$ layer of natural seawater was running over the $3 \mathrm{~cm}$ layer of spiked sediments. This was done in order to minimize cuttlefish movements required for feeding and to optimize their contact time with sediments. Juvenile cuttlefish (mean wet wt $\pm \mathrm{SD}=0.124 \pm 0.046 \mathrm{~g} ; \mathrm{n}=25$ ) were then placed for $17 \mathrm{~d}$ in the aquarium during which time the sediment and seawater radioactivity was periodically checked. These measurements showed that ${ }^{14} \mathrm{C}-\mathrm{PCB}$ radioactivity and concentration $\left(9.49 \pm 1.14 \mathrm{ng} \mathrm{g}^{-1}\right.$ dry wt) remained constant in the sediments throughout the experiment, and that no radioactivity could be detected in seawater. Cuttlefish were fed twice daily with Artemia salina and any uningested food was removed after $1 \mathrm{~h}$ and ß-counted. No activity could be detected in the brine shrimp. Cuttlefish were periodically sampled to follow PCB uptake kinetics and distribution among the tissues over time. 


\section{Uptake from food.}

Before the feeding experiment, brine shrimp were exposed for $7 \mathrm{~d}$ in a glass aquarium containing 41 of filtered seawater spiked with $18 \mathrm{ng}{ }^{14} \mathrm{C}-\mathrm{PCB} \# 153 \mathrm{l}^{-1}$ (24-h water spiking procedure as described above for seawater). Radiolabeled seawater was renewed daily and brine shrimp were regularly fed a mixture of phytoplankton. After $7 \mathrm{~d}$, brine shrimp were used to feed the juvenile cuttlefish. (Fresh brine shrimp were labeled daily to have 7-d labeled food available each day throughout the experiment.) Juvenile cuttlefish (mean wet wt $\pm \mathrm{SD}=0.130$ $\pm 0.029 \mathrm{~g} ; \mathrm{n}=25)$ were placed in individual plastic containers $(10 \mathrm{~cm}$ diameter, $5 \mathrm{~cm}$ height $)$ and held in a 701 glass aquarium (open circuit, $201 \mathrm{~h}^{-1}$ flow rate, 36 p.s.u., $16.5 \pm 0.5^{\circ} \mathrm{C}$ ). During the entire experiment $(17 \mathrm{~d})$, individuals were allowed to ingest radiolabeled A. salina twice a day for $1 \mathrm{~h}$; food was given in excess and any non-ingested shrimp remaining after the feeding period were immediately removed. Cuttlefish were periodically sampled over time to follow PCB uptake kinetics and distribution among the tissues.

\section{Data analyses.}

Uptake of the ${ }^{14} \mathrm{C}-\mathrm{PCB}$ congener from seawater, sediments and food was expressed as change in PCB concentration (ng $\mathrm{g}^{-1}$ total lipids) over time. Radiotracer uptake kinetics were described either by using a linear model (eq. 1), a saturation exponential model (eq. 2), or a combined model (logistic plus exponential) (eq. 3):

$$
\begin{aligned}
& \mathrm{C}(\mathrm{t})=\mathrm{C}_{\mathrm{o}}+\mathrm{k} \cdot \mathrm{t} \\
& \mathrm{C}(\mathrm{t})=\mathrm{C}_{\mathrm{ss}}\left(1-\mathrm{e}^{-\mathrm{k} \cdot \mathrm{t}}\right) \\
& \mathrm{Ct}=\mathrm{C}_{\mathrm{ss}}\left(1-\mathrm{e}^{-\mathrm{k} \cdot \mathrm{t}}\right) / 1+\mathrm{e}^{-\mathrm{k} .(\mathrm{t}-\mathrm{I})}
\end{aligned}
$$

where $\mathrm{C}(\mathrm{t}), \mathrm{C}_{\mathrm{o}}$, and $\mathrm{C}_{\mathrm{ss}}$ are the ${ }^{14} \mathrm{C}-\mathrm{PCB}$ concentrations (ng $\mathrm{g}^{-1}$ total lipids), respectively, at time $\mathrm{t}(\mathrm{d})$, at time 0 , and at steady-state, $\mathrm{k}$ is the rate constant $\left(\mathrm{d}^{-1}\right)$ and $\mathrm{I}$ is the time (d) at the inflexion point. The model showing the most accurate fit (based on the calculation of the determination coefficient, $\mathrm{R}^{2}$, and examination of the residuals) was used. Constants and 
statistics of the different models were estimated by iterative adjustment of the models and Hessian matrix computation, respectively, using the nonlinear curve-fitting routines in Systat ${ }^{\circledR}$ 5.2.1 (Wilkinson 1988). Differences among ${ }^{14} \mathrm{C}-\mathrm{PCB}$ concentrations in the different body compartments were tested using one-way ANOVA and the multiple comparison test of Tukey (Zar 1996). After arcsine-transformation of data (using the correction of Freeman-Tukey, 1950; in Zar 1996), changes in ${ }^{14} \mathrm{C}-\mathrm{PCB}$ body distribution were tested for significance using the G-test (adapted from the log-likelihood ratio test) for 2 x k contingency tables (Zar 1996). The level of significance for statistical tests was always set at $\alpha=0.05$.

\section{RESULTS}

Uptake kinetics of ${ }^{14} \mathrm{C}$-PCB\#153 by S. officinalis were determined by exposing juveniles via three different pathways: seawater, sediments and food. Accumulation was followed in three body compartments: digestive gland, cuttlebone and remaining tissues (which included all the other tissues and organs). Accumulation was also considered in whole-body organisms using reconstituted data of the separate tissues.

\section{Uptake from seawater}

Bioaccumulation kinetics and their parameters in the different body compartments of the cuttlefish following exposure to environmentally realistic seawater PCB concentrations (18 ng $1^{-1}$ ) are shown in Fig. 2 and Table 1. Except for cuttlebone, uptake of the contaminant was best described using linear models. Cuttlebone took up little, if any, PCB congener. Among the compartments, the remaining tissues concentrated PCB\#153 to the greatest degree, almost one order of magnitude higher than in the digestive gland and two orders of magnitude higher than in the cuttlebone ( $\mathrm{p}_{\text {Tukey test }} \leq 0.0001$ ). Concentration factors (ratio between PCB concentration in organism and in an equal weight of seawater) were calculated for the compartments considered and for the whole-body (Table 2). 
The tissue distribution of ${ }^{14} \mathrm{C}-\mathrm{PCB} \# 153$ varied significantly (log-likelihood ratio, G-test) throughout the experiment (Fig. 3). At the beginning of the experiment, all of the contaminant (100\%) was found in the remaining tissues. Then, during the first days of exposure, a progressive transfer to the digestive gland took place, reaching a peak of about $15 \%$ of the total load after $4 \mathrm{~d}$. The remaining tissues always contained the major fraction (80-100\%) of the total ${ }^{14} \mathrm{C}$-PCB body load, whereas very low proportions were found in the cuttlebone (0$2.5 \%)$.

\section{Uptake from sediments}

As observed in the seawater experiment, cuttlebone did not appear to accumulate ${ }^{14} \mathrm{C}-\mathrm{PCB}$ during sediment exposure. Accumulation kinetics in the digestive gland were best described by a combined model (logistic + exponential components), whereas accumulation in the remaining tissues and in whole organisms was best fitted by a saturation exponential model (Fig. 4, Table 1). Similar to the seawater experiment, the body compartment that took up PCB\#153 to the greatest degree was the remaining tissues. Nevertheless, transfer factors between sediments and organisms remained low, reaching maximum values of 5.3 (Table 2).

The tissue distribution of ${ }^{14} \mathrm{C}-\mathrm{PCB}$ was determined at different times during the experiment (Fig. 5). The remaining tissues contained the major fraction (84-99\%) of the total PCB body load, whereas the lowest proportions were found in the cuttlebone (0-1.3\%). At day 1 , the remaining tissues contained $99 \%$ of the radiotracer, with a progressive transfer to the digestive gland taking place during the first days of exposure and reaching a peak of about 13 $\%$ of the total load after $4 \mathrm{~d}$. This transfer is clearly indicated by the lag period in the uptake kinetics observed in the digestive gland (Fig. 4).

\section{Uptake from food}

Throughout the experiment, juvenile cuttlefish were fed radiolabeled brine shrimp ad libitum for $1 \mathrm{~h}$, twice a day. Uptake kinetics of ${ }^{14} \mathrm{C}-\mathrm{PCB} \# 153$ ingested with food followed the 
combined (logistic + exponential) model in the digestive gland and the linear model in the remaining tissues and in whole organisms (Fig. 6, Table 1). The separate body compartments (except cuttlebone) displayed PCB concentrations and transfer factors of the same order of magnitude (Fig. 6, Table 2).

As expected, the distribution of the contaminant among cuttlefish tissues determined at different times showed that at the beginning of the experiment, the ingested radiotracer was entirely associated with the digestive gland (Fig. 7). Over time, the proportion of ${ }^{14} \mathrm{C}-\mathrm{PCB}$ activity significantly decreased in the digestive gland and increased in the remaining tissues $(\mathrm{G}$ test, $\mathrm{p}<0.05)$.

\section{DISCUSSION}

Cephalopods are well-known for their capacity to accumulate radioactive, metallic or organic contaminants to relatively high levels (see e.g. Ueda et al. 1979, Miramand \& Bentley 1992, Yamada et al. 1997, Bustamante et al. 2000). However, only few studies have aimed at investigating the concentrations and distribution of PCBs in these mollusks, and most of these studies have only considered whole organisms as a source of contaminant for their predators (Tanabe et al. 1984, Kawano et al. 1986, Weisbrod et al. 2000, 2001). Some studies have employed cephalopods as bioindicators of local or global PCB contamination (Butty \& Holdway 1997, Yamada et al. 1997, Ueno et al. 2003), and other ones have demonstrated cellular or tissue effect of organic pollutants (Mann et al. 1988, Cheah et al. 1995). Nevertheless, a review of available literature clearly shows a general lack of information regarding bioaccumulation processes in cephalopods.

The present experimental work, exposing the common cuttlefish $S$. officinalis to environmentally realistic concentrations of a radiolabeled PCB congener, demonstrated the potential of these organisms to bioconcentrate PCBs to high levels. The bioconcentration efficiency was far greater when cuttlefish were exposed through seawater compared to either 
the food or sediment pathways. Indeed, PCB\#153 concentration factors (CFs) from seawater were 2 to 3 orders of magnitude higher than transfer factors from sediment or food. These differences are in close agreement with observations from sea stars and sea urchins exposed to the same contaminant under similar conditions (Danis et al. 2003a,b).

The distribution of the radiolabeled PCB congener was examined in three body compartments (the digestive gland, cuttlebone and the remaining tissues of juvenile cuttlefish) and the design of the experiments allowed following the uptake kinetics of the PCB in the separate body compartments. The digestive gland was selected, since this organ plays a major role in the energetic metabolism of cephalopods (Boucaud-Camou \& Boucher-Rodoni 1983) and has been documented to accumulate PCBs to high levels (Yamada et al. 1997, Ueno et al. 2003). The cuttlebone was also examined as this calcareous compartment acts as an internal skeleton and represents ca. $3 \%$ of the total body weight of the juveniles. Finally, the third compartment (remaining tissues) comprises the rest of the animal (ca. $90 \%$ of the total body weight) and mainly consists of muscles. The tracer experiments showed a similar distribution pattern between the three compartments irrespective of the source of exposure: fractions of the radiolabeled PCB were always much higher in the remaining tissues, followed by the digestive gland and with very little amounts in the cuttlebone. Following exposure via seawater, sediments and food, the cuttlebone did not significantly concentrate the PCB congener. In fact, the cuttlebone contained less than $2.5 \%$ of the total contaminant load and only for a limited period of time. This is likely due to the internal localization of the cuttlebone which appears to have no direct contact with ambient seawater and to the low fat content of this tissue.

In contrast to the cuttlebone, the digestive gland readily accumulates PCB\#153. The highest concentrations in the digestive gland were reached following seawater exposure. After $17 \mathrm{~d}$ of exposure, juvenile cuttlefish continued to concentrate the PCB in their digestive gland in a linear fashion. On the other hand, PCB\#153 uptake in the digestive gland displayed saturation kinetics following both sediment and food exposures. These results are particularly surprising 
for the digestive gland as it (a) has no direct contact with ambient seawater and (b) plays a major role in the digestive processes, including nutrient absorption. However, this organ is also involved in detoxification processes of xenobiotics in cephalopods (Cheah et al. 1995, Bustamante et al. 2002). Therefore, elevated concentrations in the digestive gland could result more from transfers from other organs accumulating compounds to be detoxified than from actual bioconcentration in the digestive gland itself. At this stage, it is difficult to explain the precise role of the cuttlefish digestive gland in the metabolism of PCBs; however, complex PCB redistribution processes clearly do occur among the tissues of this cephalopod. Therefore, it would be of major interest to characterize precisely the distribution of PCBs in adult cephalopods by making a finer separation of all tissues and organs.

Among the three compartments examined in these experiments, most of the PCB\#153 taken up ( $\geq 80 \%$ ) was located in the remaining tissues regardless of the exposure pathway. However, the PCB concentration factors $(\mathrm{CF})$ calculated in the remaining tissues following the seawater experiment was three orders of magnitude higher than transfer factors (TFs) computed at the end of the sediment or food experiments. The fact that the remaining tissues are in direct contact with seawater could explain such a very high degree of accumulation following seawater exposure. However, cuttlefish also spend a substantial part of their time in very close contact with sediments; therefore, differences between CF and TFs most probably also reflect differences in PCB bioavailability between the seawater and sediment pathways.

The uptake kinetics of PCB\#153 in the remaining tissues followed a linear model when cuttlefish were exposed via seawater or food, and a saturation model when exposed via sediments. Saturation concentrations were relatively low if compared to studies with sea stars exposed to sediments spiked with similar PCB\#153 concentrations (Danis et al. 2003a). Sea stars displayed the same uptake kinetics but reached much higher PCB\#153 concentrations, especially in compartments in direct contact with sediments $\left(\geq 3,000 \mathrm{ng} \mathrm{g}^{-1}\right.$ lipids in the body wall). 
Even if the cuttlefish used in this study were early juveniles, the results following seawater, sediment and food exposures have shown that PCBs are incorporated to high levels in their tissues. Even though this study was a first approach to understanding the pathways of PCB contamination in cephalopods, it highlights the general lack of knowledge concerning mechanisms underlying PCB bioaccumulation, distribution and depuration. Finally, the main finding from this study is that seawater appears to be the main route for PCB incorporation in juvenile cuttlefish. Assuming that cuttlefish are representative of cephalopods in general, these mollusks might therefore be useful bioindicators of the ambient water PCB contamination (Yamada et al. 1997, Ueno et al. 2003). On the other hand, many cephalopod species from contaminated areas could play a major role in the transfer of these Persistent Organic pollutants to their predators. 


\section{Acknowledgements}

We thank Prof. E. Boucaud-Camou for advice on rearing cuttlefish. The IAEA Marine Environment Laboratory operates under a bipartite agreement between the International Atomic Energy Agency and the Government of the Principality of Monaco. BD is holder of a

FRIA doctoral grant. MW is a Honorary Research Associate of the National Fund for Scientific Research (NFSR, Belgium). Research was supported by a Belgian Federal Research Programme (SSTC, Contract MN/11/30) and by a NFSR short-term fellowship to M. Warnau.

\section{REFERENCES}

Atuma SS, Linder CE, Andersson Ö, Bergh A, Hansson L, Wicklund-Glynn A (1996) CB153 as indicator for congener specific determination of PCBs in diverse fish species from Swedish waters, Chemosphere 33(8):1459-1464

Barnes H, Blackstock J (1973) Estimation of lipids in marine animals and tissues : detailed investigation of the sulfophosphovanillin for «total lipids», J. Exp. Mar. Biol. Ecol., $12: 103-118$

Boucaud-Camou E, Boucher-Rodoni R (1983) Feeding and digestion in Cephalopods. In: Saleuddin ASM, Wilbur KM (eds) The Mollusca, Vol. 5. Physiology, Part 2. New York and London, Academic Press, p 149-187

Bustamante P, Grigioni S, Boucher-Rodoni R, Caurant F, Miramand P (2000) Bioaccumulation of 12 trace elements in the tissues of the nautilus Nautilus macromphalus from New-Caledonia. Mar Pollut Bull 40(8):688-696 
Bustamante P, Cosson RP, Gallien I, Caurant F, Miramand P (2002) Cadmium detoxification processes in the digestive gland of cephalopods in relation to accumulated cadmium concentrations. Mar Environ Res 53:227-241

Butty JS, Holdway DA (1997) Assessment of the octopus Octopus pallidus, as a potential bioindicator of xenobiotic challenge: baseline studies. Mar Pollut Bull 34(7):564-570

Castro BG, Guerra A (1990) the diet of Sepia officinalis (Linnaeus 1758) and Sepia elegans (D’Orbigny 1835) (Cephalopoda, Sepioidea) from the Ria de Vigo (NW Spain), Sci. Mar. $54: 375-388$

Cheah DMY, PFA Wright, DA Holdway, JT Ahokas (1995) Octopus pallidus cytochrome P450: characterization and induction studies with ß-naphthoflavone and Aroclor 1254. Aquatic Toxicology 33:201-214

Clark RB (1997) Marine Pollution. Clarendon Press, Oxford.161 pp

Clarke MR (1996) Cephalopods as prey. III. Cetaceans. Philos Trans R Soc Lond Ser B 351:1053-1065

Croxall JP, Prince PA (1996) Cephalopods as prey. I. Seabirds. Philos Trans R Soc Lond Ser B 351:1023-1043

Danis B., Cotret O., Teyssié J.-L., Fowler S.W., Bustamante P. \& M. Warnau (2003a). Delineation of PCB uptake pathways in a benthic sea star using a radiolabelled congener. Mar Ecol Prog Ser 253: 155-163

Danis B., J.L. Teyssié, P. Bustamante, O. Cotret, Fowler S.W., M. Warnau (2003b) Biokinetics of ${ }^{14} \mathrm{C}$-labelled $2,2^{\prime}, 4,4^{\prime}, 5,5^{\prime}$ hexachlorobiphenyl (PCB\#153) in the echinoid Paracentrotus lividus: seawater and food exposures, in press (Environmental Pollution) 
Forsythe JW, Heukelem WF (1987) Growth, In : Boyle PR (ed), Cephalopod life cycles, vol. 2, Academic Press London, pp 351-365

Kawano M, Matsushita S, Inoue T, Tanaka H, Tatsukawa R (1986) Biological accumulation of chlordane compounds in marine organisms from the northern North Pacific and Bering Sea. Mar Pollut Bull, 17:512-516

Klages NTW (1996) Cephalopods as prey. II. Seals. Philosophical Transactions of the Royal Society London Series, 351:1045-1052

Livingstone DR, Chipman JK, Lowe DM, Minier C, Mitchelmore CL, Moore MN, Peters LD, Pipe RK (2000) development of biomarkers to detect the effects of organic pollution on aquatic invertebrates : recent molecular, genotoxic, cellular and immunological studies on the common mussel (Mytilus edulis L.) and other mytilids. Int. J. Environ. Pollut. 13(16) :56-91

Mann T, Martin AW, French M (1988) Entry of pollutants from seawater into the spermatophore and spermatozoa of the giant octopus of the North Pacific. Mar Pollut Bull 19(12):669-671

Metcalfe CD (1994) Polychlorinated biphenyls, In: Kiceniuk JW \& Ray S (eds), Analysis of contaminants in edible aquatic resources, $\mathrm{VCH}, \mathrm{pp} 305-338$

Miramand P, Bentley D (1992) Concentration and distribution of heavy metals in tissues of two cephalopods, Eledone cirrhosa and Sepia officinalis, from the French coast of the English Channel. Mar Biol 114:407-414

Murdoch MH, Chapman PM, Norman DM, Quintino VM (1997) Spiking sediment with organochlorines for toxicity testing, Environ. Toxicol. Chem. 16(7):1504-1509 
Navarro JC, Villanueva R (2000) Lipid and fatty acid composition of early stages of cephalopods: an approach to their lipid requirements, Aquaculture 183: 161-177

Rodhouse PG, Nigmatullin CM (1996) Role as consumers. Phil. Trans R. Soc. Lond. B $351: 1003-1022$

Smale MJ (1996) Cephalopods as prey. IV. Fishes. Phil Trans R Soc Lond B 351:1067-1081

Stebbing ARD, Dethlefsen V, Carr M (eds), 1992, Biological effects of contaminants in the North Sea, Mar. Ecol. Prog. Ser. 91 (special edition)

Tanabe S, Tanaka H, Tatsukawa R (1984) Polychlorobiphenyls, DDT, and hexachlorocyclohexane isomers in the western North Pacific ecosystem. Arch Environ Contam Toxicol, 13:731-738

Tanabe S, Tatsukawa R, Phillips DJH (1987) Mussels as bioindicators of PCB pollution: a case study on uptake and release of PCB isomers and congeners in green-lipped mussels (Perna viridis) In Hong Kong waters. Environ Pollut 47: 41-62

Ueda T, Nakahara M, Ishii T, Suzuki Y, Suzuki H (1979) Amounts of trace elements in marine cephalopods. J Radiat Res 20:338-342

Ueno D, Inoue S, Ikeda K, Tanaka H, Yamada H, Tanabe S (2003) Specific accumulation of polychlorinated biphenyls and organochlorine pesticides in Japanese common squid as a bioindicator. Environ Pollut 125:227-235

Weisbrod A, Shea D, Leblanc G, Moore M, Stegeman JJ (2000) Organochlorine bioaccumulation and risk for whales in a Northwest Atlantic food web. Mar Environ Res, $50: 431-441$ 
Weisbrod A, Shea D, Moore M, Stegeman JJ (2001) Species, tissue and gender-related organochlorine bioaccumulation in white-sided dolphins, pilot whales and their common prey in the Northwest Atlantic. Mar Environ Res 51:29-50

Wilkinson L (1988) Systat: the system for statistics. Systat Inc, Evanston, IL

Yamada H, Takayanagi K, Tateishi M, Tagata H, Ikeda K (1997) Organotin compounds and polychlorinated biphenyls of livers in squid collected from coastal waters and open ocean. Environ Pollut, 96(2), 217-226

Zar JH (1996) Biostatistical Analysis, $3^{\text {rd }}$ ed. Prentice-Hall, Upper Saddle River, NJ. 850 p 


\section{CAPTIONS TO FIGURES:}

Figure 1. Schematic representation of sample processing before $\beta$-spectrometry analysis

Figure 2. Sepia officinalis. Uptake from seawater of ${ }^{14} \mathrm{C}-\mathrm{PCB} \# 153$ in the different body compartments of juvenile cuttlefish (mean concentration in $\mathrm{ng} \mathrm{g}^{-1}$ total lipids $\pm \mathrm{SD}, \mathrm{n}=3$ )

Figure 3. Sepia officinalis. PCB distribution (mean \%) among the different body compartments along the seawater experiment.

Figure 4. Sepia officinalis. Uptake from sediments of ${ }^{14} \mathrm{C}-\mathrm{PCB} \# 153$ in the different body compartments of juvenile cuttlefish (mean concentration in $\mathrm{ng}^{-1}$ total lipids $\pm \mathrm{SD}, \mathrm{n}=3$ )

Figure 5. Sepia officinalis. PCB distribution (mean \%) among the different body compartments along the sediments experiment.

Figure 6. Sepia officinalis. Uptake from food of ${ }^{14} \mathrm{C}-\mathrm{PCB} \# 153$ in the different body compartments of juvenile cuttlefish (mean concentration in $\mathrm{ng} \mathrm{g}^{-1}$ total lipids $\pm \mathrm{SD}, \mathrm{n}=3$ )

Figure 7. Sepia officinalis. PCB distribution (mean \%) among the different body compartments along the food experiment. 


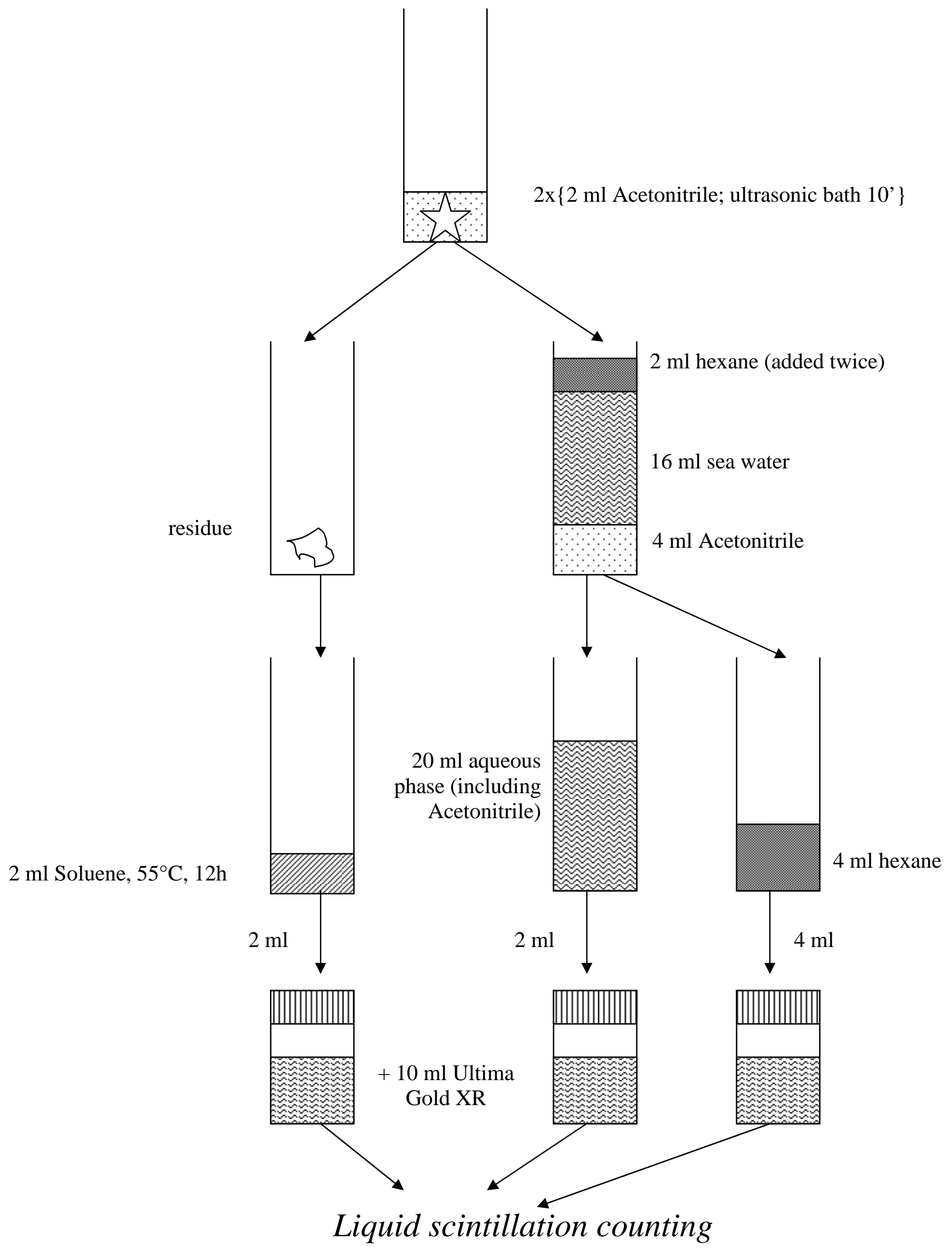



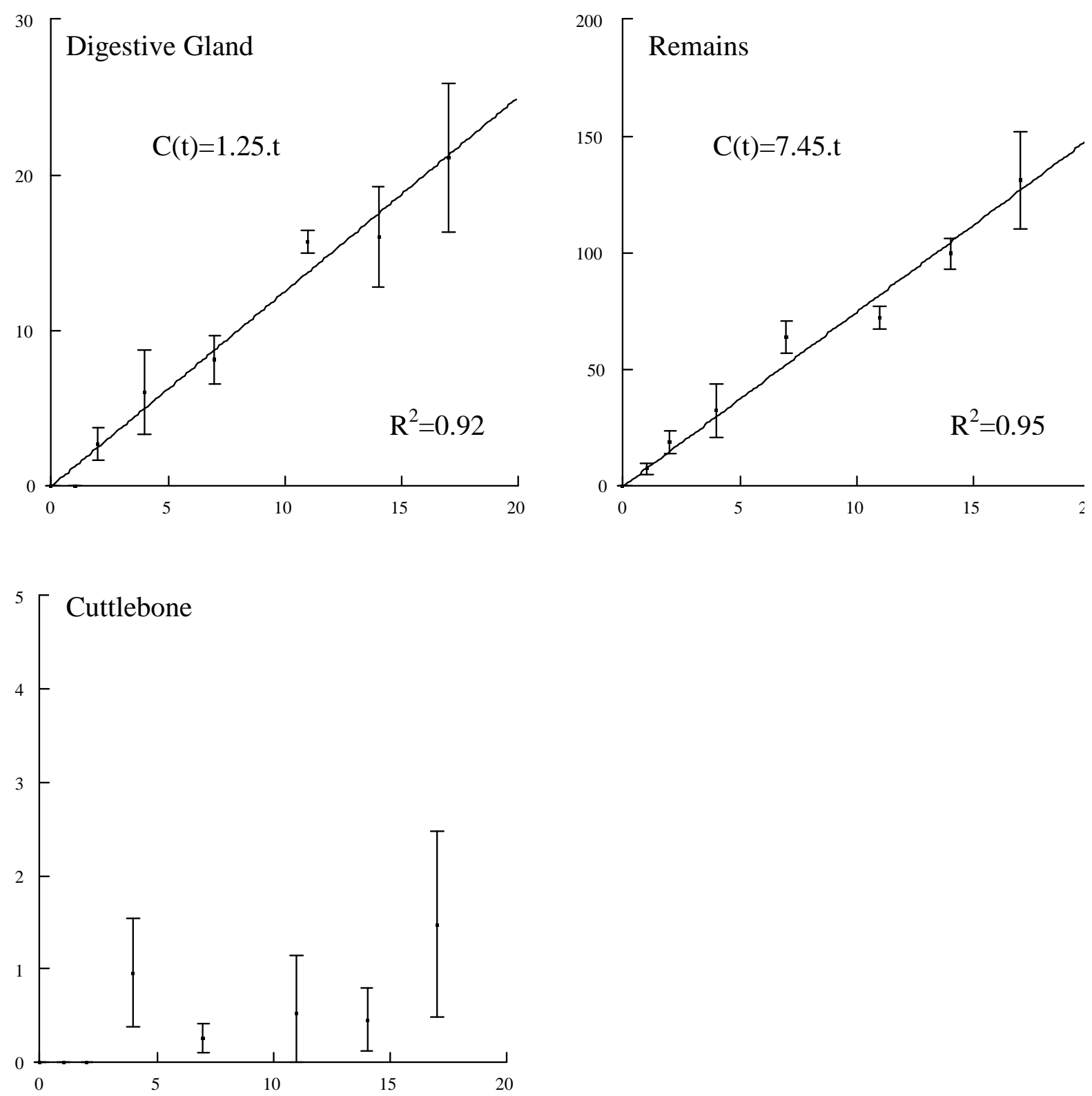

Figure 2 
$\square$ Digestive Gland $\square$ Cuttlebone $\square$ Remains

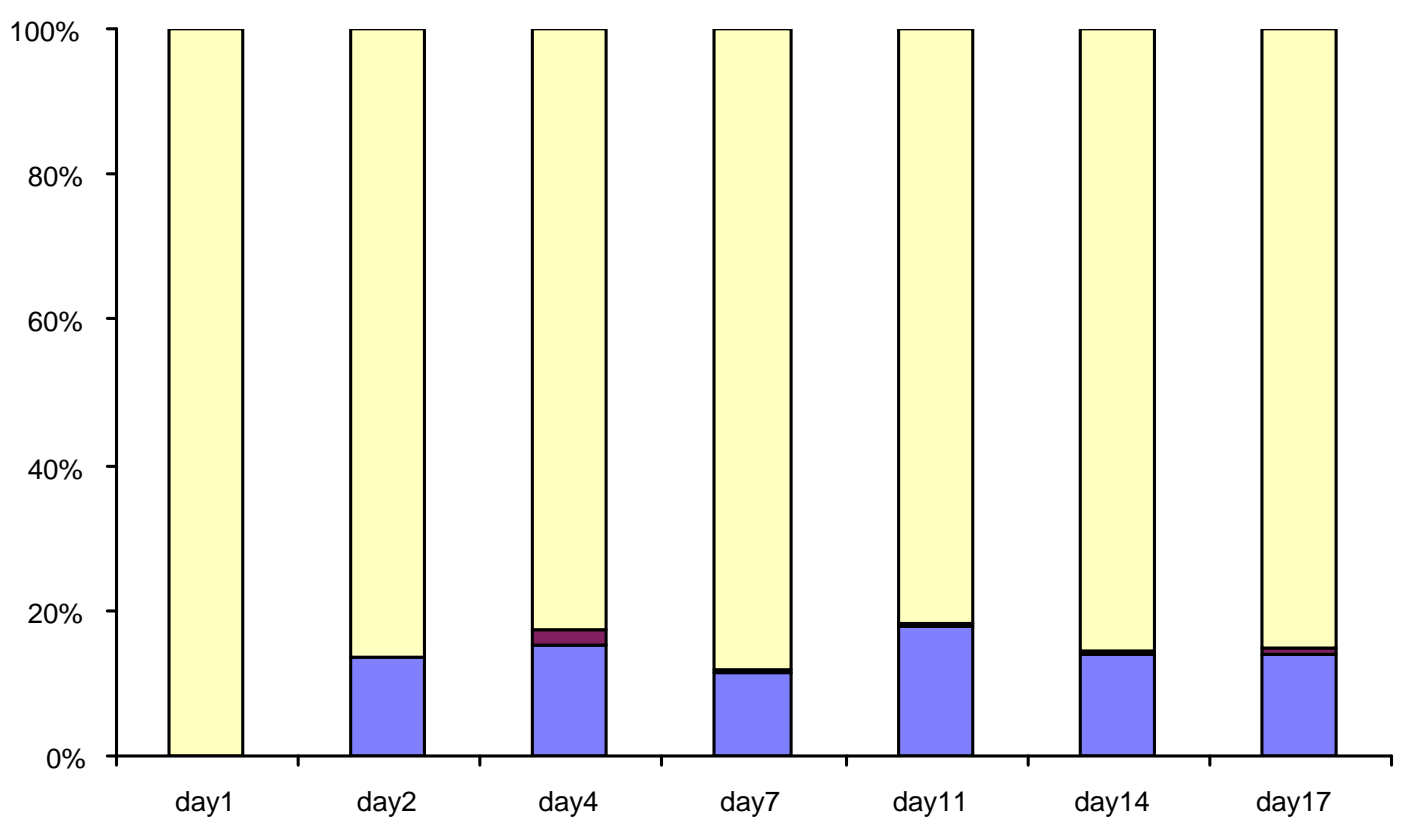

Figure 3 


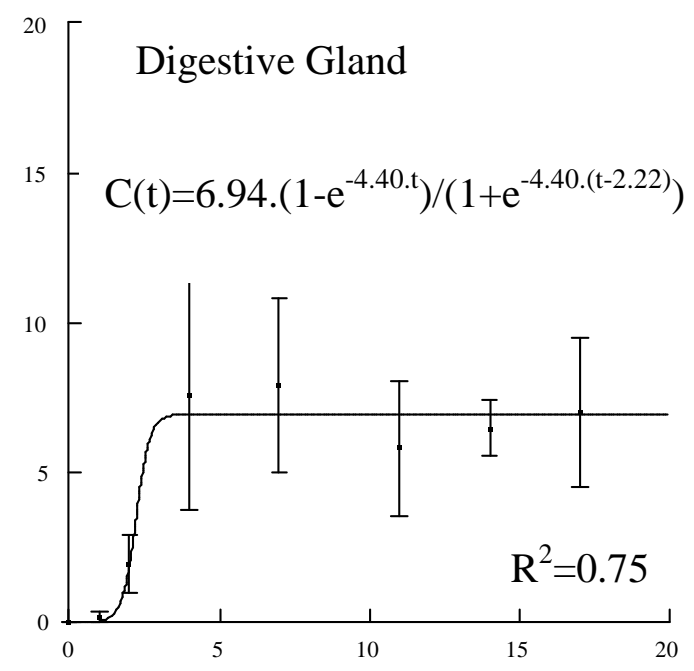

100 Remains
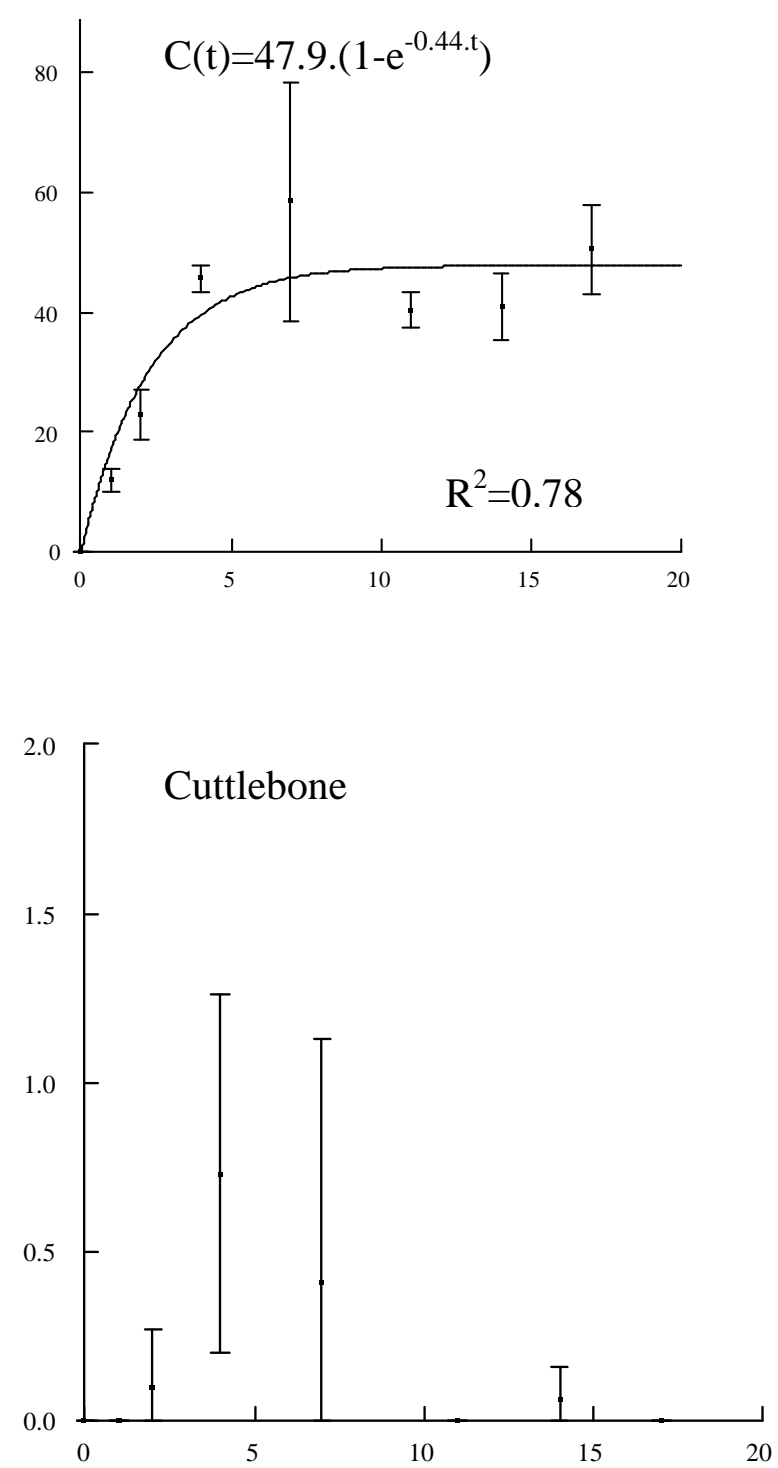

Figure 4 
D Digestive Gland $\quad$ Cuttlebone $\square$ Remains

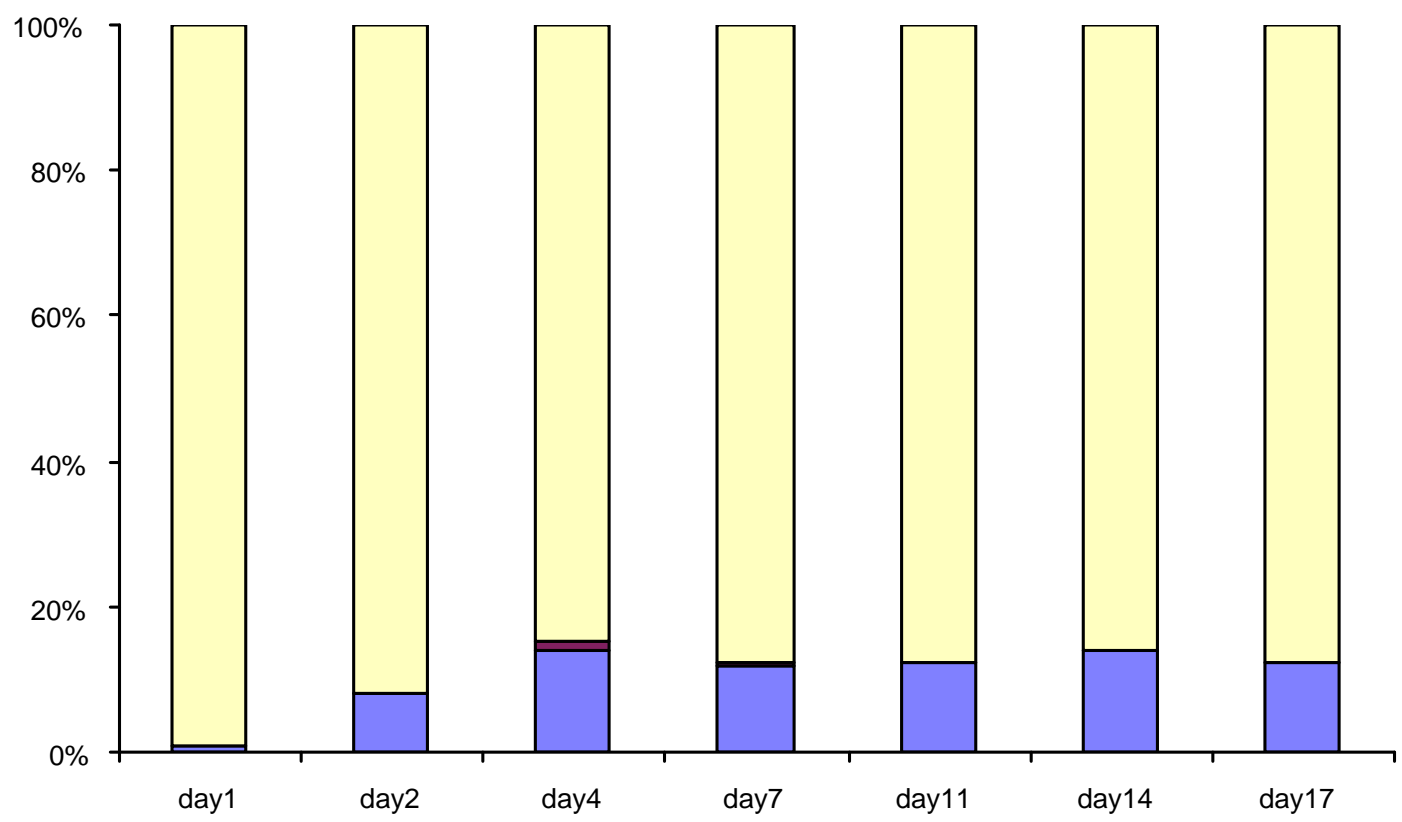

Figure 5 

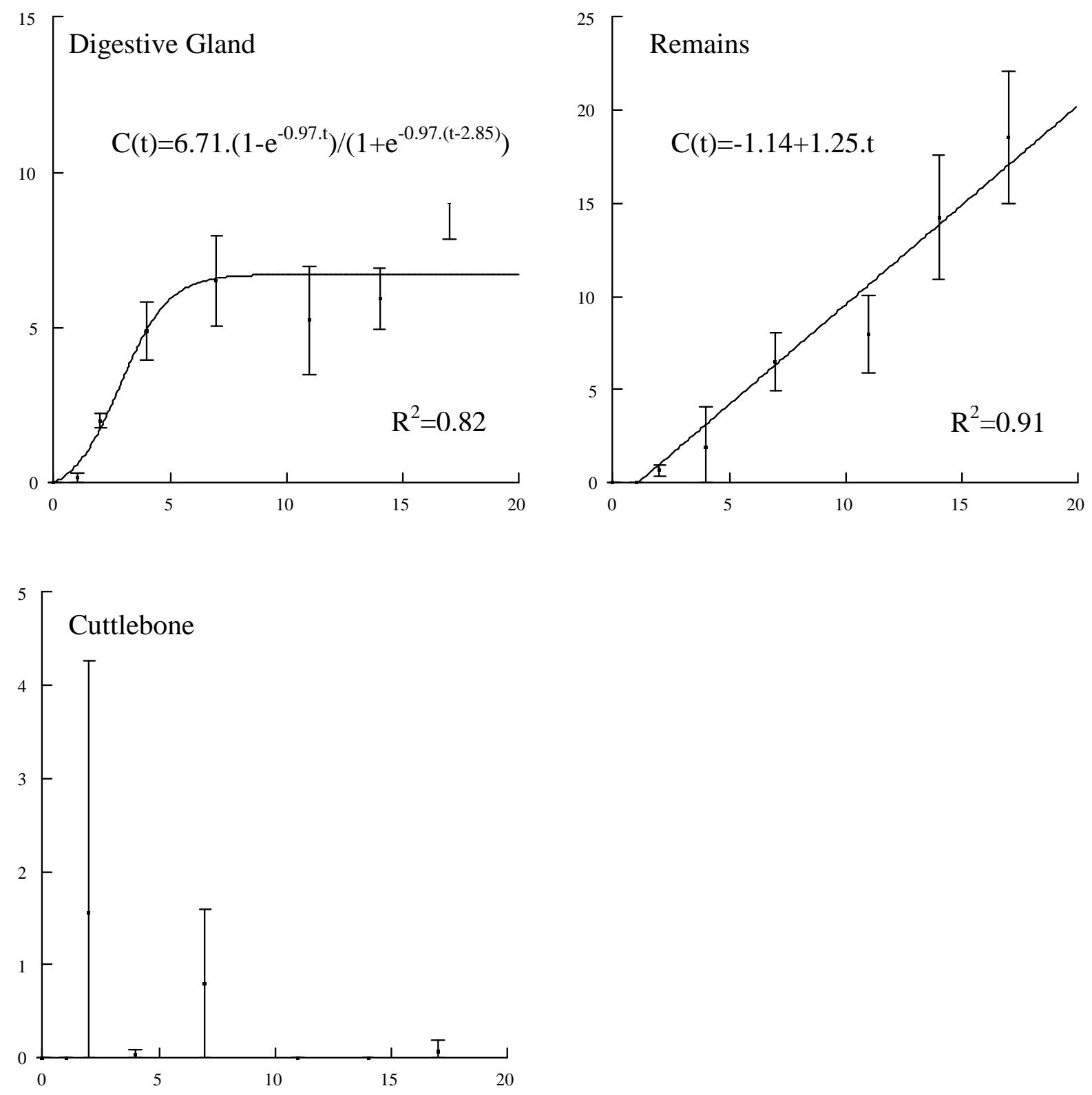

Figure 6 
$\square$ Digestive Gland $\boldsymbol{\square}$ Cuttlebone $\boldsymbol{\square}$ Remains

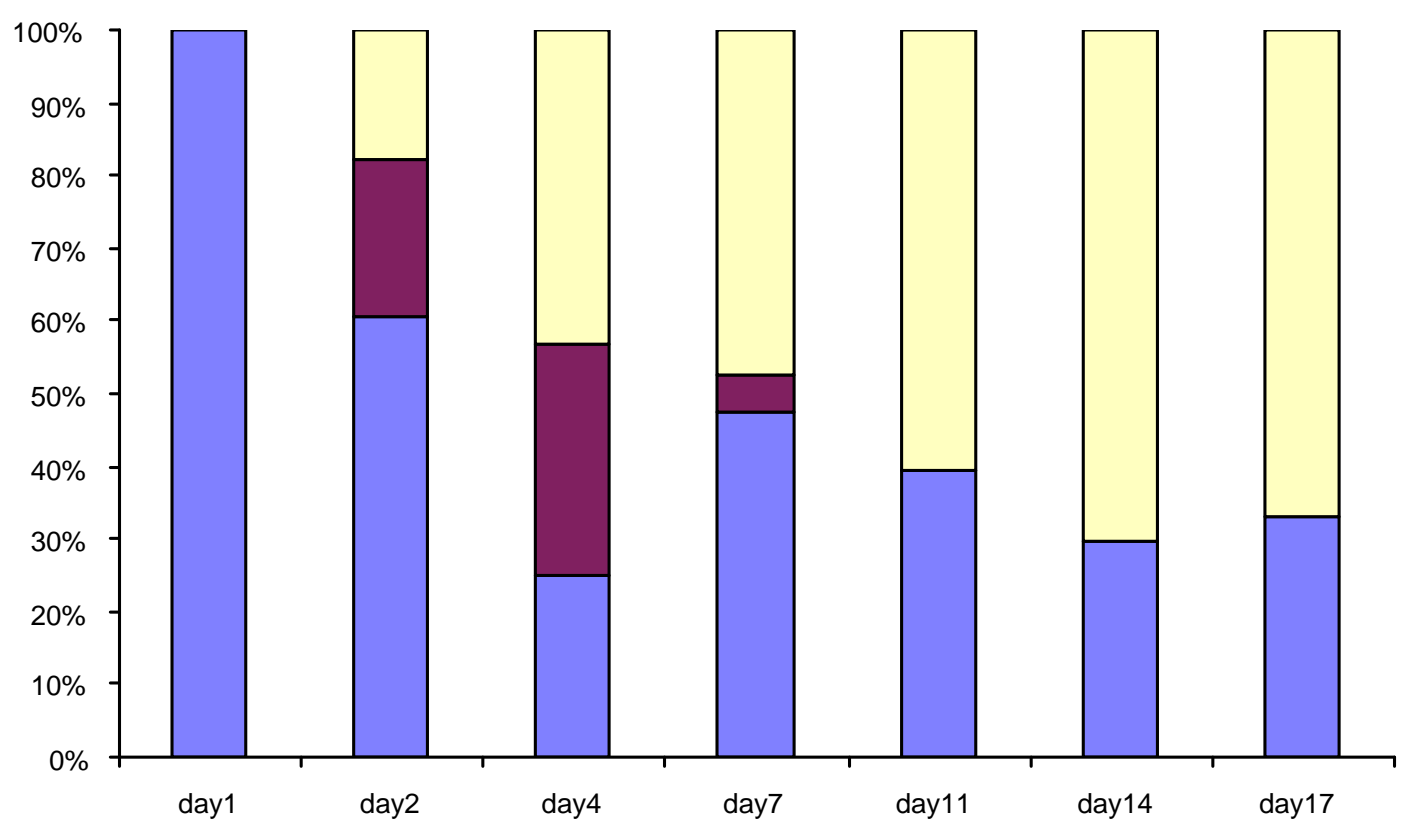

Figure 7 
